\title{
Plasmids Capable of Transfer and Chromosome Mobilization in Acinetobacter calcoaceticus
}

\author{
By K. J. TOWNER AND A. VIVIAN \\ School of Biological Sciences, Thames Polytechnic, London, SE 18 6PF
}

(Received I5 December 1976; revised 28 February 1977)

INTRODUCTION

The $\mathrm{P}$ incompatibility group plasmid RP4 (Datta et al., 197I) was recently shown to mediate conjugation in Acinetobacter calcoaceticus (Towner \& Vivian, 1976a). RP4 is probably identical to the plasmids designated $\mathrm{R}_{1} 822, \mathrm{R}_{1} 8$ and $\mathrm{RPI}$ (Holloway \& Richmond, 1973). Recombinants are formed in A. calcoaceticus at a frequency of $\mathrm{IO}^{-6}$ to $\mathrm{IO}^{-8}$ per recipient cell. In spite of this relatively low frequency of gene transfer, the system has already provided meaningful data on linkage relationships in this species, including the demonstration that the linkage map of $A$. calcoaceticus is circular (Towner \& Vivian, 1976b). However, the fact that recombination only occurs on a solid surface means that genetic analysis is time consuming and would be greatly facilitated if the frequency of recombinant formation could be increased.

In Pseudomonas aeruginosa, the plasmid RI822 (alias RP4) was inefficient in promoting chromosome mobilization (Stanisich \& Holloway, 197I), while closely related plasmids, for example R9I69 (alias R9I), mobilized the chromosome efficiently. Other plasmids of the $\mathrm{P}$ incompatibility group might, therefore, be more efficient than $\mathrm{RP}_{4}$ in mediating chromosome transfer in $A$. calcoaceticus.

In this paper we report on the ability of a range of $\mathrm{P}$ incompatibility group plasmids to transfer chromosomal genes in $A$. calcoaceticus. Experiments were also performed to test for transfer to $A$. calcoaceticus of members of the $\mathrm{C}, \mathrm{F}, \mathrm{I}$, and $\mathrm{W}$ incompatibility groups from Escherichia coli and the $\mathrm{P}_{2}$ incompatibility group from $P$. aeruginosa in the hope that other groups of plasmids might also act as efficient sex factors in this species.

\section{METHODS}

Bacterial strains. The strains of $E$. coli $\mathbf{K I} 2$ (Clowes \& Hayes, I968) used were: J53 (F-, pro, met); J53.I

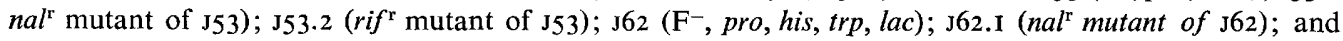
c60o (F-, thr, leu, thy, lac). The P. aeruginosa strain used was PAOI (FP-, prototroph) (Holloway, I969). The strains of $A$. calcoaceticus EBF65/65 (Towner \& Vivian, 1976a) used were: C4I7 (trp, str $r^{\mathrm{r}}$ [high-level]); $\mathrm{C} 426$ (trp, his); and $\mathrm{C} 478$ (phe, thi).

Plasmids used are listed in Table I.

Media used were as described previously (Towner \& Vivian, 1976a).

Antibiotics were obtained from Sigma (except where indicated) and were added to media as freshly prepared solutions at the following final concentrations $\left(\mu \mathrm{g} \mathrm{ml}^{-1}\right)$ : tetracycline hydrochloride, 5 ; sodium ampicillin (Beecham Research Laboratories), 500; trimethoprim, 500; sulfadiazine, 500; gentamicin sulphate, Io; and dihydrostreptomycin sulphate, 2000 .

Millipore mating technique. This technique was used for all matings as described by Towner \& Vivian $(1976 a)$. After resuspension from the filter the cells were sedimented and resuspended in the same volume of quarter-strength Ringer's solution before plating out. This procedure eliminated any background growth due to carry-over of auxotrophic requirements.

Test for plasmid stability. The stabilities of the different plasmids transferred to $A$. calcoaceticus were compared by picking a single colony from antibiotic-containing medium into nutrient broth and incubating for $24 \mathrm{~h}$ at $28^{\circ} \mathrm{C}$ on a rotary shaker. The resulting suspension was plated out for single colonies on minimal medium and then replicated to plates of minimal medium containing the appropriate selective antibiotic. 
Table I. Plasmids

\begin{tabular}{|c|c|c|c|}
\hline Plasmid* & $\begin{array}{l}\text { Incompatibility } \\
\text { group }\end{array}$ & Resistance markers $\dagger$ & Reference \\
\hline $\mathbf{R P}_{4}$ & $\mathbf{p}$ & $\mathrm{A}, \mathrm{Tc}, \mathrm{K}$ & Datta et al. (I97I) \\
\hline R75I & $\mathbf{P}$ & $\mathrm{Tp}$ & Jobanputra \& Datta (1974) \\
\hline Rro33 & $\mathbf{P}$ & $\mathrm{A}, \mathrm{Tc}, \mathrm{K}, \mathrm{Ge}, \mathrm{S}, \mathrm{Su}, \mathrm{C}$ & Smith et al. (1975) \\
\hline R9I & $\mathbf{P}$ & $\mathrm{A}, \mathrm{Tc}, \mathrm{K}$ & Stanisich \& Holloway (197I) \\
\hline $\mathrm{R}_{702}$ & $\mathbf{P}$ & $\mathrm{Tc}, \mathrm{K}, \mathrm{S}, \mathrm{Su}$ & Hedges \& Jacob (1974) \\
\hline $\mathbf{R}_{\mathrm{GN} 823}$ & $\mathbf{P}$ & $\mathrm{A}, \mathrm{Tc}, \mathrm{K}, \mathrm{S}, \mathrm{Su}, \mathrm{C}$ & Sawai et al. (1970) \\
\hline R68.45 & $\mathbf{p}$ & $\mathrm{A}, \mathrm{Tc}, \mathrm{K}$ & Haas \& Holloway (1976) \\
\hline $\mathrm{R}_{3} 88$ & W & $\mathrm{Su}, \mathrm{Tp}$ & Datta \& Hedges $(1972 a)$ \\
\hline S-a & W & $\mathrm{K}, \mathrm{Su}, \mathrm{S}, \mathrm{C}$ & Watanabe, Furuse \& Sakaizumi (1968) \\
\hline R4oa & $\mathrm{C}$ & $\mathrm{A}, \mathrm{K}, \mathrm{Su}$ & Datta \& Hedges $(1972 b)$ \\
\hline $\mathrm{R}_{57 \mathrm{~b}}$ & $\mathrm{C}$ & $\mathrm{A}, \mathrm{Ge}, \mathrm{Su}, \mathrm{C}$ & Datta \& Hedges (I972 $b$ ) \\
\hline RPLiI & $\mathbf{P}_{2}$ & $\mathrm{~A}, \mathrm{Tc}, \mathrm{K}, \mathrm{Ge}, \mathrm{S}, \mathrm{Su}, \mathrm{C}$ & Korfhagen \& Loper (I975) \\
\hline RI-16 & $F_{\text {II }}$ & $\mathrm{A}, \mathrm{K}, \mathrm{S}, \mathrm{Su}, \mathrm{C}$ & Meynell \& Cooke (I969) \\
\hline R64 & $\mathrm{I}_{\alpha}$ & $\mathrm{Tc}, \mathrm{S}$ & Lawn et al. (1967) \\
\hline
\end{tabular}

${ }^{*}$ RP4 and R68.45 were obtained from Dr J. E. Beringer, John Innes Institute, Norwich. All other plasmids were obtained from Dr R. W. Hedges, Royal Postgraduate Medical School, London WI 2.

$\dagger A$, ampicillin; S, streptomycin; Tc, tetracycline; K, kanamycin; C, chloramphenicol; Su, sulphonamides; $\mathrm{Tp}$, trimethoprim; Ge, gentamicin.

\section{RESULTS}

Ability of plasmids to transfer to A. calcoaceticus

The $\mathrm{P}$ incompatibility group plasmids used in this study were all transferable from $E$. coli KI 2 to $A$. calcoaceticus using the Millipore mating method and selecting for acquisition of the indicated antibiotic resistance marker (Table 2). Other antibiotic resistance markers carried by these plasmids (except for kanamycin resistance) were also expressed in $A$. calcoaceticus and levels of resistance were comparable to those found in the $\mathrm{R}^{+} E$. coli donor. It was not possible to measure accurately the level of resistance conferred by the kanamycin plasmid marker because $A$. calcoaceticus EBF65/65 already carries a chromosomal marker specifying resistance to this antibiotic.

Crosses were also performed in an attempt to detect transfer of the $\mathrm{C}$ group plasmids $\mathrm{R} 40 a$ and $\mathrm{R} 57 b$, the F-like plasmid $\mathrm{R}_{\mathrm{I}} \mathrm{I} 6$, the I-like plasmid $\mathrm{R} 64$ and the $\mathrm{W}$ group plasmids $\mathrm{R} 388$ and S-a from their $E$. coli hosts to $A$. calcoaceticus. Jacoby (1975) has reported that $\mathrm{C}$ and $\mathrm{W}$ plasmids are transferable from $E$. coli to $P$. aeruginosa. Transfer of RI-I 6 and R64 was tested because these plasmids transfer at high frequency between $E$. coli strains and have been used to mediate chromosomal transfer between members of the Enterobacteriaceae (Meynell \& Cooke, I969; Dixon \& Postgate, I971). However none of these plasmids was transferable to $A$. calcoaceticus at a detectable level ( $>\mathrm{I}$ in $10^{9}$ ).

RPLI I is a plasmid from $P$. aeruginosa belonging to incompatibility group $\mathrm{P}_{2}$ (Korfhagen \& Loper, 1975). Plasmids of this incompatibility group can be transferred between different species of Pseudomonas but cannot be transferred to members of the Enterobacteriaceae (Shahrabadi, Bryan \& Van Den Elzen, 1975). The ability of RPLi I to transfer to $A$. calcoaceticus was tested by mating $P$. aeruginosa PAOI(RPLII) with the streptomycinresistant (high-level) strain $\mathrm{C} 4 \mathrm{I}$ 7, and then selecting for tetracycline-resistant and streptomycin-resistant (high-level), tryptophan-requiring cells. Transfer was not observed.

\section{Transfer of $P$ incompatibility group plasmids and chromosomal genes between strains of $A$. calcoaceticus}

Mating experiments were performed between auxotrophic mutants of $A$. calcoaceticus to determine the frequency of transfer of $\mathrm{P}$ incompatibility group plasmids in $A$. calcoaceticus and also the frequency of transfer of chromosomal genes (Table 3). Most of these plasmids promoted chromosomal gene transfer in $A$. calcoaceticus at detectable frequencies. The 
Table 2. Transfer of $P$ incompatibility group plasmids

between E. coli and A. calcoaceticus

Escherichia coli donor strains were mated with $\mathrm{C478}$ ( $\mathrm{phe}$ thi) using the Millipore mating technique as described in Methods. Selection was made for $\mathrm{C} 478$ cells which had acquired the indicated plasmid antibiotic resistance marker. Frequencies of transfer are expressed as $\mathrm{R}^{+}$recipients per recipient. The abbreviations are defined in Table $\mathbf{I}$.

$\begin{array}{lcc}\text { Donor } & \begin{array}{c}\text { Selected } \\ \text { marker }\end{array} & \begin{array}{c}\text { Mean frequency } \\ \text { of transfer }\end{array} \\ \text { J53(RP4) } & \text { Tc } & \mathrm{I} \cdot 0 \times 10^{-5} \\ \text { J62(R75I) } & \text { Tp } & 3 \cdot 2 \times 10^{-8} \\ \text { J53.2(RI033) } & \text { Tc } & 3.4 \times 10^{-6} \\ \text { J53.2(R9I) } & \text { Tc } & 6 \cdot 2 \times 10^{-6} \\ \text { J62(R702) } & \text { Tc } & 3 \cdot 9 \times 10^{-5} \\ \text { J53.2(R }\left(R_{\text {GN823 }}\right) & \text { Tc } & 5 \cdot 0 \times 10^{-4} \\ \text { J53(R68.45) } & \text { Tc } & I \cdot 1 \times 10^{-6}\end{array}$

Table 3. Transfer of A. calcoaceticus chromosomal genes by $P$ incompatibility group plasmids

Strain $\mathrm{C} 478$ (phe thi) carrying the different plasmids was mated with strain $\mathrm{C} 426$ (his trp) using the Millipore mating technique. Selection was made against both auxotrophic markers contained in the donor and for the acquisition of either $h^{+}$or $t r p^{+}$by the recipient. Frequencies of plasmid transfer are expressed as $\mathbf{R}^{+}$recipients per recipient.

\begin{tabular}{lcrr} 
& $\begin{array}{c}\text { Frequency of } \\
\text { plasmid transfer }\end{array}$ & \multicolumn{2}{c}{$\begin{array}{c}\text { No. recombinants per } 10^{8} \\
\text { recipient cells }\end{array}$} \\
Plasmid & $2.0 \times 10^{-5}$ & 146 & trp $^{+}$ \\
RP4 $_{\text {R751 }}$ & $6.3 \times 10^{-5}$ & 45 & 44 \\
R1033 & $8.2 \times 10^{-6}$ & 17 & 28 \\
R9I & $8.8 \times 10^{-6}$ & 0 & 17 \\
R702 & $2.5 \times 10^{-3}$ & 57 & 0 \\
R $_{\text {GN823 }}$ & $7.6 \times 10^{-3}$ & 229 & 64 \\
R68.45 & $5.3 \times 10^{-7}$ & 0 & 89
\end{tabular}

number of recombinants obtained varied slightly between experiments but, in general, for each individual plasmid the frequency of chromosomal gene transfer was enhanced by an increased frequency of independent plasmid transfer.

The relative frequencies of the two types of recombinants varied for the different plasmids used (Table 3). Since RP4 donates the chromosome from at least two different sites (Towner $\&$ Vivian, $1976 b$ ), some of these plasmids may be of value in mapping studies if, as seems possible, they have different donor properties.

Of particular interest is the result obtained with R68.45. This plasmid is a variant of R68 and was reported to be efficient in transferring chromosomal genes of both $P$. aeruginosa (Haas \& Holloway, 1976) and Rhizobium leguminosarum (Beringer \& Hopwood, 1976). However, in A. calcoaceticus R68.45 was only transferred at the comparatively low frequency of $5.3 \times 10^{-7}$ and transfer of chromosomal genes was not detected.

\section{Stability of $P$ incompatibility group plasmids in A. calcoaceticus}

The frequency of plasmid transfer might be governed by the instability of the plasmid in the donor strain. Towner \& Vivian (1976a) showed that RP4 was slightly unstable in $A$. calcoaceticus. The stabilities of the different $\mathbf{P}$ group plasmids used in this study were therefore compared. However, although all the plasmids tested were slightly unstable in A. calcoaceticus (normally about $5 \%$ instability), the degree of stability of each individual 
plasmid varied between experiments and there was no correlation between this and the frequency of plasmid transfer. The factors controlling $\mathrm{P}$ plasmid stability in $\mathrm{A}$. calcoaceticus remain to be determined.

\section{DISCUSSION}

The object of this investigation was to examine a variety of plasmids belonging to different incompatibility groups in an attempt to find one which would transfer the $A$. calcoaceticus chromosome at a higher frequency than the original system using RP4. However, of the plasmids tested, only members of the $\mathbf{P}$ incompatibility group were capable of transfer to A. calcoaceticus, and none of these showed great variation from the levels of chromosome transfer obtained with RP4. Indeed some plasmids (R9I and R68.45) which were more efficient than $\mathrm{RP}_{4}$ in promoting chromosome transfer in $P$. aeruginosa (Stanisich \& Holloway, I97I ; Haas \& Holloway, 1976), were unable to do so at a detectable level in A. calcoaceticus. As R68.45 is also an efficient promotor of chromosome mobilization in $R$. leguminosarum (Beringer \& Hopwood, I976), it seems that the ability of $\mathbf{P}$ incompatibility group plasmids to mobilize chromosomal markers may be species specific.

The frequency of chromosome transfer using a particular plasmid was related to the frequency of independent plasmid transfer, but varied considerably with the mobilizing plasmid (Table 3). One possible way to increase the frequency of plasmid transfer (and hence the frequency of chromosome mobilization) would be to isolate a derepressed mutant. However Dennison \& Baumberg (1975), working with $E$. coli, suggested that $\mathrm{P}$ incompatibility group plasmids were already naturally derepressed, but that this was masked by the incompetence in liquid matings of donors carrying them. In A. calcoaceticus, RP4 transfer occurs at a low frequency in broth matings and is increased if matings are carried out on a solid surface, while chromosome transfer can only be detected on a solid surface (Towner \& Vivian, 1976 b). A similar situation therefore appears to exist. Other attempts to increase the frequency of recombinant formation using ultraviolet light and mitomycin $\mathrm{C}$ at the levels of survival used by Evenchik, Stacey \& Hayes (1969) had no detectable effect in $A$. calcoaceticus (K. J. Towner, unpublished results).

Thus, it is probable that any future attempt to produce a high frequency conjugation system in $A$. calcoaceticus would benefit from a search for any self-transmissible plasmids that might already be naturally present. The demonstration that some strains of Bacterium anitratum (A. calcoaceticus) contain extrachromosomal circular DNA molecules (Christiansen et al., 1973) suggests that such a search could be profitable.

We would like to thank all those who have encouraged us and donated bacterial strains and plasmids. We are especially grateful to Dr R. W. Hedges for his many helpful suggestions during the course of this work and to Mr D. Matthews for his technical support.

\section{REFERENCES}

Beringer, J. E. \& Hopwood, D. A. (I976), Chromosomal recombination and mapping in Rhizobium leguminosarum. Nature, London 264, 29I-293.

Christiansen, C., Christiansen, G., Leth BaK, A. \& STENDERUP, A. (1973). Extrachromosomal deoxyribonucleic acid in different enterobacteria. Journal of Bacteriology 114, 367-377.

Clowes, R. C. \& HAYES, W. (1968). Experiments in Microbial Genetics. Oxford and Edinburgh: Blackwell Scientific Publications.

DatTA, N. \& Hedges, R. W. (r972a). Trimethoprim resistance conferred by $\mathrm{W}$ plasmids in Enterobacteriaceae. Journal of General Microbiology 72, 349-356.
DatTa, N. \& Hedges, R. W. (I972 $b)$. R factors identified in Paris, some conferring gentamycin resistance, constitute a new compatibility group. Annales de l'Institut Pasteur 123, 849-852.

Datta, N., Hedges, R. W., Shaw, E. J., Sykes, R. B. \& Richmond, M. H. (I97I). Properties of an $\mathrm{R}$ factor from Pseudomonas aeruginosa. Journal of Bacteriology 108, I 244-I 249.

Dennison, S. \& BaumberG, S. (I 975). Conjugational behaviour of $\mathrm{N}$ plasmids in Escherichia coli $\mathrm{KI} 2$. Molecular and General Genetics 138, 323-33I.

Dixon, R. A. \& Postgate, J. R. (I97I). Transfer of nitrogen-fixation genes by conjugation in Klebsiella pneumoniae. Nature, London 234, 47-48. 
Evenchik, Z., Stacey, K. A. \& Hayes, W. (i969). Ultraviolet induction of chromosome transfer by autonomous sex factors in Escherichia coli. Journal of General Microbiology 56, I-14.

HaAs, D. \& Holloway, B. W. (I976). R factor variants with enhanced sex factor activity in Pseudomonas aeruginosa. Molecular and General Genetics 144, 243-25I.

Hedges, R. W. \& JACOB, A. E. (1974). Transposition of ampicillin resistance from $\mathrm{RP}_{4}$ to other replicons. Molecular and General Genetics 132, 3 I-40.

Holloway, B. W. (1969). Genetics of Pseudomonas. Bacteriological Reviews 33, 419-443.

Holloway, B. W. \& Richmond, M. H. (1973). $\mathrm{R}$ factors used for genetic studies in strains of Pseudomonas aeruginosa and their origin. Genetical Research 21, 103-105.

JaCOBY, G. A. (1975). Properties of R plasmids in Pseudomonas aeruginosa. In Microbiology - I974, pp. 36-42. Edited by D. Schlessinger. Washington, D.C.: American Society for Microbiology.

Jobanputra, R. S. \& DatTa, N. (I974). Trimethoprim resistance factors in enterobacteria from clinical specimens. Journal of Medical Microbiology 7, I69-177.

KorfHAGEN, T. R. \& Loper, J. C. (I975). RPLiI, an $\mathrm{R}$ factor of Pseudomonas aeruginosa determining carbenicillin and gentamycin resistance. Antimicrobial Agents and Chemotherapy 7, 69-73.

Lawn, A. M., Meynell, G. G., Meynell, E. \& Datta, N. (I967). Sex pili and the classification of sex factors in the Enterobacteriaceae. Nature, London 216, 343-346.
Meynell, E. \& Cooke, M. (1969). Repressor-minus and operator-constitutive de-repressed mutants of F-like $\mathrm{R}$ factors: their effect on chromosomal transfer by HfrC. Genetical Research 14, 309-3I3.

Sawai, T., Takahashi, K., Yamagishi, S. \& Mitsuhashi, S. (1970). Variant of penicillinase mediated by an $\mathrm{R}$ factor in Escherichia coli. Journal of Bacteriology 104, 620-629.

Shahrabadi, M.S., Bryan, L. E. \& VAN DeN ELZEN, H. M. (I975). Further properties of P2 R-factors of Pseudomonas aeruginosa and their relationship to other plasmid groups. Canadian Journal of Microbiology 21, 592-605.

Smith, D. I., Gomez Lus, R., Rubio Calvo, M. C., DatTA, N., JACOB, A. E. \& Hedges, R. W. (I975). Third type of plasmid conferring gentamycin resistance in Pseudomonas aeruginosa. Antimicrobial Agents and Chemotherapy 8, 227-230.

Stanisich, V. A.\& Holloway, B. W. (197I). Chromosome transfer in Pseudomonas aeruginosa mediated by $\mathrm{R}$ factors. Genetical Research $\mathbf{1 7}$, I69-I 72.

TOWNER, K. J. \& ViVIAN, A. (I976a). RP4-mediated conjugation in Acinetobacter calcoaceticus. Journal of General Microbiology 93, 355-360.

Towner, K. J. \& Vivian, A. (I976b). Conjugation in Acinetobacter calcoaceticus: different donor strains. Proceedings of the Society for General Microbiology 3, 178 .

Watanabe, T., Furuse, C. \& Sakaizumi, S. (I968), Transduction of various $\mathbf{R}$ factors by phage $\mathrm{PI}$ in Escherichia coli and by phage $\mathrm{P}_{22}$ in Salmonella typhimurium. Journal of Bacteriology 96, I79II795. 